\title{
Field Dependence / Field Independence as a Factor of Financial Decision Making With Varying Degrees of Risk Among Students
}

\author{
Belykh Tatiana Viktorovna ${ }^{1 *}$, Zinchenko Ekaterina Mikhailovna ${ }^{1}$
}

1Department of Psychology, Saratov National Research University named after N.G. Chernyshevsky, Russian Federation, e-mail: tvbelih@mail.ru; Odonata1108@yandex.ru

\begin{abstract}
Currently, a new interdisciplinary field of research - financial behaviour-is rapidly developing. Psychological characteristics of the subject of financial behaviour can have a significant impact on the decision-making process in this field. Cognitive style, as an individual way of processing the information perceived by the subject, is one of the factors determining such procedural features of financial decision-making as: the time spent on decision - making, the speed of decision-making, the emotional state of the individual during decision-making, the nature of perceptual information processing (especially oculomotor activity), as well as the type of decision strategy - rational, irrational or marginal.
\end{abstract}

Keywords: decision-making, risk, field dependence / field independence, oculomotor activity.

\section{Introduction}

The problem of research of psychological features and multi-factor determination of the decisions made by the person remains relevant today. For the first time this question was raised by Kahneman, D., and Tversky, A. (1979) in their work on the Theory of Prospects. They suggested that a person's choice is not always rational. On the contrary, we often make mistakes and act irrationally when making financial decisions. With the help of a series of experiments they managed to show and prove that a person is governed by psychological patterns at the time of making financial decisions. The problem of studying the decision-making process and its psychological components remains relevant to modern scientific knowledge. In the works of Neumann, J., and Morgenstein, O. (1970) in the framework of game theory and optimal control theory the first approaches to its study were formulated and the main stages of decision-making (construction of alternatives, their evaluation and selection of the optimal alternative) were identified. American psychologists Petty, R. E., and Cacioppo, J. T. (1986) developed an elaboration likelihood mode (ELM) of conscious information processing that describes the effect of persuasive message on the recipient from the point of view of its relationship to the subject of the message that can be used in understanding of the decision-making process.

A great contribution to the solution of this problem on the part of the Russian scientists was made by Kornilova, T. V. (2010) and her students who developed a theory that reveals the unity of the intellectual and personal potential of a person in decision-making. At the same time gender, age and individual-personal differences in decision-making processes were found (Zaguzova T. A., 2009), cognitive-style determination of decision-making was revealed (Semicheva N. V., 2010), the adoption of innovative solutions in terms of managerial competence of the individual was investigated (Ponomarev V. P., 2011), the specifics of decision-making processes in the situation of advertising exposure was revealed (Gladkih N. Yu, 2011), data on the psychological conditions of managerial decision-making by managers in stressful situations were obtained (Akhtamov V. S., 2013). Age aspect of decision-making has become the subject of study in the works of Bryukhova, N. G. (2007), who concentrated attention on the impact of self-reflection on decision-making process among young girls and boys, Rumyantseva, $\mathrm{A}$. V. (2008), who studied the peculiarities of decision-making of high school students in situations of risk, which are manifested in the subjective representations of risk and decision-making, in the predominance of a particular type of risk, the characteristics of the flow of the decision-making process, in greater "riskiness" and less rationality than adults, Krivosheeva, N. W. (2008), who studied socio-psychological readiness of students-future managers to take managerial decisions, which includes motivational, value-orientation, assessment, operational, ethical-volitional and individual components.

"Corresponding author: tvbelih@mail.ru 
At present, a new interdisciplinary field of knowledge - behavioural finance is developing. "Behavioural Finance is the direction of the financial theory that arose more than 30 years ago, whose distinctive feature is the use of the construction of financial models of the irrational component of individual cognitive processes" (Goretskaya V. A., 2014, p. 28). In this direction, within the framework of Economics and economic psychology, researches are conducted by such scientists as: Grishina N. P., 2012; Mordashkina Yu., 2013; Goretskaya V. A., 2014; Korshunova G. V., Nemtsev A. D., and Romanova L. E., 2017; Cechin V.V., 2017, etc.). As for foreign researchers, it is worthwhile mentioning such researchers as Loewenstcin, 1996; Carmon, Z. and Ariely, D. 2000; Ariely, D. and Wertenbroch, K. 2002, Ariely, Loewenstein, and Prelec, 2003; Ariely, D., Bracha, A., and L'Huillier, J.-P. 2010; Shiv B., Carmon Z., and Ariely D., 2005; Samson, A., 2015.

Individual cognitive features along with perception, memory and thinking (Kornilova, 2002; Vavilov, 2005; Nenasheva, 2009), which influence the financial decision-making process, include cognitive style as well. Cognitive style reflects the enduring characteristics of how different people think, perceive and remember information, as well as their preferred way of solving problems (Shkuratova, 1994, 1999; Kholodnaya, 1997).

Currently, there is a large number of works on the study of cognitive styles. Field dependence / field independence (FD / FID) is one of the parameters of cognitive style, described for the first time by G. Witkin, who considered it as one of the manifestations of psychological differentiation of a personality (Witkin, 1997). Depending on the person, the factor of influence of the field (subject and social environment) reveals itself in different measure. Thus, the behaviour of some people is more subordinated to the field (field dependent type of behaviour), while the behaviour of others is aimed at internal activity (field independent type of behaviour) (Kholodnaya, 1992, 1997). In a number of studies the impact of this style on mental abilities, on peculiarities of perception are examined, the issue of the development of style in the process of growing up, as well as the impact of gender on the manifestation of perceptual style are considered (Tikhomirova, 1988; The Style of the Person, 1998; Kholodnaya, 1990, 2002; Predein, 2012). So, Semyashkin, A. A. (2010) found out gender differences in the interrelations of cognitive styles (field dependence/field independence, narrowness-width of the range of equivalence) and temperament; Osokina, K. A. (2016) revealed the connection of the field of dependence/ field of independence with such stable characteristics of the personality as stress resistance, anxiety, procedural components of thinking.

The process of financial decision-making is multi-factor determination, which includes the impact of a biologically-determined psychological properties, for example, neuro - and psycho-dynamic individual differences (Belykh T. V., 2016) and socially-determined factors, which, in particular, consider the rationality/irrationality of decision-making (Belykh T., Grishina N., and Zinchenko E., 2018).

The aim of the present study is to identify the features of financial decision-making in simulated conditions with varying degrees of risk among field dependent/field independent students.

\section{Materials and Methods}

The study was conducted in a higher educational establishment on the basis of the educational laboratory "Cognitive Psychology". The experiment involved 77 people (85\% of girls, $15 \%$ of boys), studying at the psychological, biological and mechanical-mathematical faculties.

The experiment consisted of several stages. In the first stage, the Gottschaldt Figure test was used to diagnose the cognitive style of FD / FID students (Gottschaldt, 1926). The test consists of thirty tasks in which it is proposed to find one masked element among the five reference ones. One complex figure and 5 reference elements, coded with the letters A, B, C, D, E, were shown on the Eye Tracker screen.

At the second stage the test "Coin Lottery" was used to assess the risk (Belykh T., Grishina N., and Zinchenko E., 2018). This test consists of 2 groups of financial tasks: 1 group - winning problems, 2 group - losing ones. Each group includes 2 types of questions depending on the degree of risk: 0.99 and 0.01 . Financial tasks were presented one by one on the Eye Tracker screen and the participant of the experiment had to choose between two answers: to take a risk or to choose a guaranteed win or loss.

The experiment was carried out with the use of a hardware method for detection of oculomotor activity by video recording of the participant's gaze movements, carried out by a stationary binocular eye tracking system Eye Tracker (model RED 500 System, produced by SMI (SensoMotoriklnstruments $\mathrm{GmbH}$, Germany). Initial processing of the basic characteristics of eye movements was produced by the BeGaze program of the Eye Tracker installation. During the test, various parameters of oculomotor activity were recorded, including indicators of blinking, fixation and saccades.

Upon presentation of two alternatives, the experimenter has the information about previously 
calculated mathematical expectation and dispersion (as a risk measure) for this choice, which allowed assessing the degree of manifestation of rationality in the decision-making of each participant. The results were carefully analyzed and subdivided into groups with varying degrees of rationality of the decisions made. The following definitions of specific solutions are used in the conducted analysis: rational (+); risk avoiding (RA); risk seeking (RS); loss avoiding (LA); irrational (-).

To determine membership in a particular group, the expectation and dispersion (risk measure) of the risk option are compared with the same parameters of the guaranteed outcome. After detailed analysis of the decisions of each participant, the entire study sample should be divided into groups depending on the rationality of the decisions taken. According to Markowitz, (1952), a rational investor prefers more to less and certainty to uncertainty. Thus, we believe that the percentage of rationality is a sum total of rational and risk-avoiding decisions in the total number of proposed choices (+ and RA).

The rationality of risk behaviour was determined depending on the number of risk responses given by the respondent, as well as taking into account the mathematical expectation and sigma for each task.

So 3 groups of personalities were singled out:

- strictly rational (>60\% of rationality);

- marginal (60-40\% of rationality);

- strictly irrational $(<40 \%$ of rationality).

The same procedure is used to determine the rationality of decisions in subgroups of financial situations of choice: wins with a probability of 0.99 , wins with a probability of 0.01 , losses with a probability of 0.99 , losses with a probability of 0.01

The obtained data were processed by SPSS program. The Kolmogorov-Smirnov criterion was used to determine the nature of the distribution of the data obtained. Further, in accordance with the result, non-parametric analysis methods were used: Mann-Whitney statistical criterion and Spirmen correlation analysis.

\section{Results}

In the course of the experiment, according to the results of the "Gottschaldt Figures" test, which determines the cognitive style, 2 groups of respondents were identified: group 1 - field independent students (24\%), group 2 - field dependent students (76\%) (Figure 1).

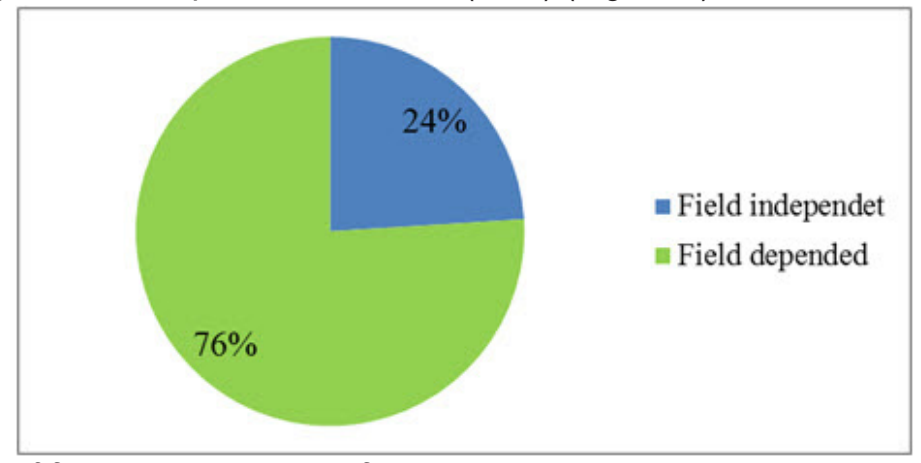

Figure 1. Ratio of field dependent and field independent students

Thus, the majority of respondents have low articulated experience. This is probably due to the fact that most of the test participants are girls. Field dependence is more typical for female representatives in all age groups, while field independence - for males (Shkuratova, 1994).

According to the results of the analysis of respondents' answers while solving financial problems in each group, depending on the rationality of the choice, rational, marginal and irrational students were identified (Figure 2). 


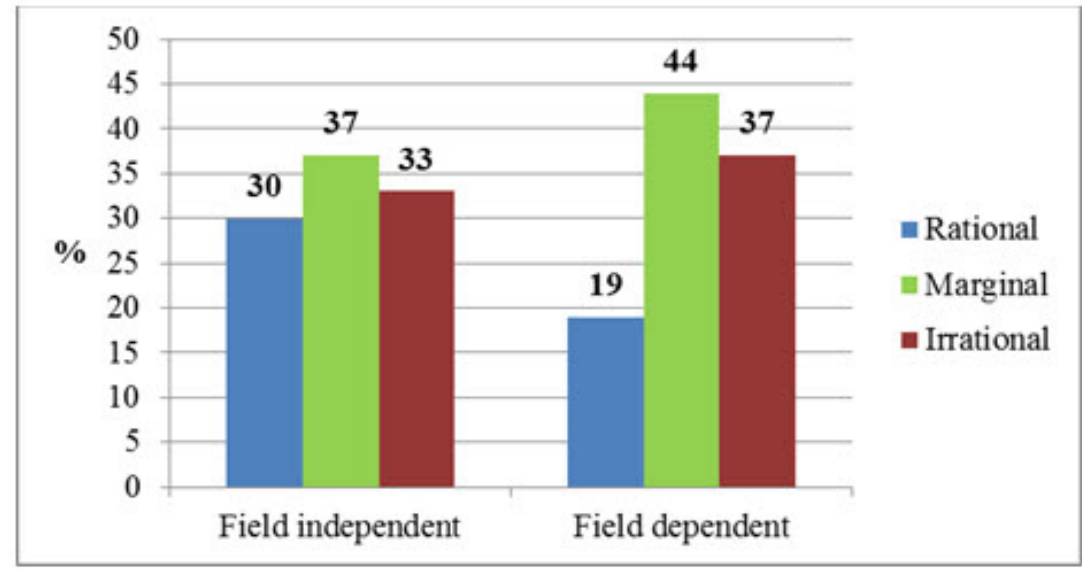

Figure 2. Distribution of field independent / field dependent students taking into account the rationality of choice

Both the field-independent and the field-dependent groups are dominated by representatives who are inclined to make decisions using both rational and irrational strategies, and their number is $37 \%$ and $44 \%$ respectively. The distribution based on rationality / irrationality among field-dependent students was approximately equal: $30 \%$ and $33 \%$ respectively. But among the field-dependent students the use of rational decision-making strategy is typical for $19 \%$ of respondents. The remaining $37 \%$ of respondents used an irrational strategy when making a financial decision.

Thus, the least amount of use of rational decision-making strategy among students is found in the group with a field-dependent perceptual style.

The correlation between the field dependence index and the level of rationality was not revealed by the results of the correlation analysis as for FID and FD students.

The percentage ratio of students was also revealed, taking into account the index of field-dependency by the number of risk-related responses in solving financial problems with different probability of win / loss (Figure 3).

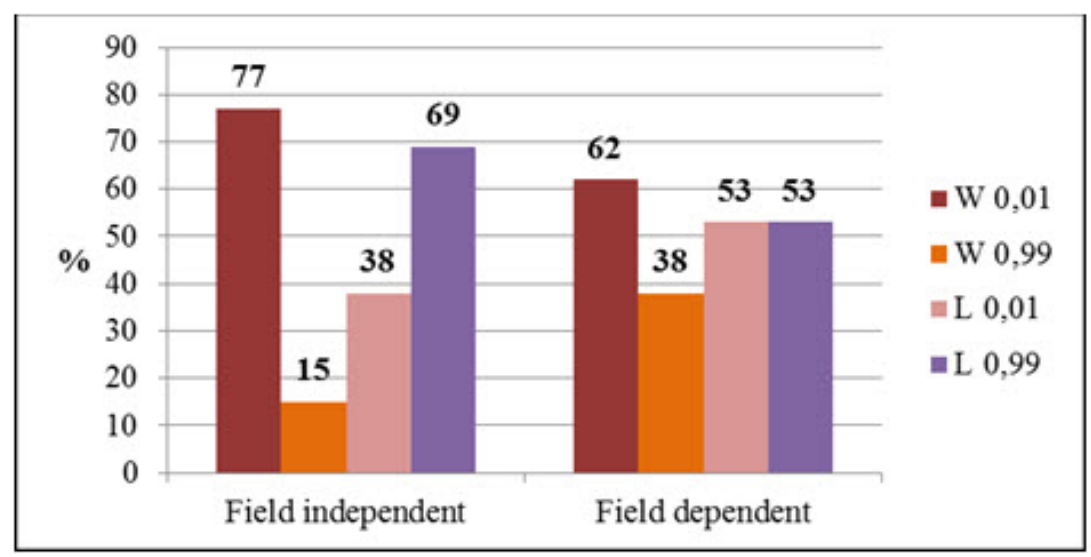

Figure 3. Distribution of students, taking into account the field dependency index by the number of risky answers.

Note: W 0.01 - tasks with winning probability of $1 \%$, W 0.99 - tasks with winning probability of $99 \%$, L 0.01 - tasks with lossing probability of $1 \%$, L 0.99 - tasks with losing probability of $99 \%$.

Thus, students are more likely to risk in winning situations with a probability of $1 \%$. It is worth noting that for FD students probability of loss does not matter, and for FID students the choice of risk increases with a probability of loss of $99 \%$.

Further, a correlation analysis was performed, during which FD students were found to have a negative correlation relationship between number of risk responses and field dependence index when solving winning tasks with a probability of $1 \%(r=-0.402, p \leq 0.05)$ and excluding probability $(r=-0.415, p$ $\leq 0.05$ ). Thus, the more significant the cognitive style - field dependence is, the less risk-related responses are given by respondents.

At the next stage, the analysis of oculomotor activity (OMA) of students in the simulated conditions 
of financial decision-making was carried out.

The results of the Kolmogorov-Smirnov test showed that the variables of OMA have significant deviations from the normal distribution $(p<0.05)$. According to the results of the statistical analysis by the Mann-Whitney criterion, significant differences in oculomotor activity were found in students with different cognitive styles. But taking into consideration the fact that similar differences in OMA were found while solving problems with different degrees of probability of winning and losing, the description of the results will be the same on the example of winning problems with a probability of 0.99 (Table 1).

Table 1

OMA indicators for students with different cognitive styles in solving financial tasks with a probability of winning 0.99

\begin{tabular}{|c|c|c|c|c|}
\hline & Options & FID & FD & \\
\hline 1 & End Time [ $\mathrm{ms}$ ] & $7266 \pm 897$ & $8699 \pm 736$ & * \\
\hline 2 & Blink Count & $2.99 \pm 4.05$ & $3.30 \pm 3.04$ & \\
\hline 3 & Blink Frequency [ count / s] & $0.355 \pm 0.40$ & $0.334 \pm 0.37$ & \\
\hline 4 & Blink Duration Total [ ms ] & $854 \pm 1325$ & $753 \pm 989$ & \\
\hline 5 & Blink Duration Average [ ms ] & $241 \pm 151$ & $207 \pm 54$ & \\
\hline 6 & Blink Duration Maximum [ ms] & $597 \pm 57$ & $190 \pm 137$ & * \\
\hline 7 & Blink Duration Minimum [ ms] & $91.2 \pm 17.1$ & $105.4 \pm 37.3$ & \\
\hline 8 & Fixation Count & $21.5 \pm 2.01$ & $26.0 \pm 1,71$ & * \\
\hline 9 & Fixation Frequency [ count / s] & $2.99 \pm 0.51$ & $3.00 \pm 0.72$ & \\
\hline 10 & Fixation Duration Total [ ms ] & $3941 \pm 125$ & $4567 \pm 134$ & * \\
\hline 11 & Fixation Duration Average [ms ] & $207 \pm 19$ & $167 \pm 12$ & * \\
\hline 12 & Fixation Duration Maximum [ms ] & $546 \pm 115$ & $333 \pm 87$ & * \\
\hline 13 & Fixation Duration Minimum [ms ] & $58.8 \pm 12.2$ & $58.8 \pm 16,6$ & \\
\hline 14 & Fixation Dispersion Total [ px] & $1627 \pm 115$ & $1905 \pm 163$ & * \\
\hline 15 & Fixation Dispersion Average [px ] & $109 \pm 35,4$ & $70.82 \pm 19,5$ & \\
\hline 16 & Fixation DispersionMaximum [ px ] & $425 \pm 53.9$ & $347 \pm 63,9$ & \\
\hline 17 & Fixation Dispersion Minimum[ $p x$ ] & $11.52 \pm 2,45$ & $24.19 \pm 4,13$ & * \\
\hline 18 & Scanpath Length [ px ] & $4941 \pm 225$ & $5941 \pm 327$ & * \\
\hline 19 & Saccade Count & $37.3 \pm 3.29$ & $50.5 \pm 7.61$ & * \\
\hline 20 & Saccade Frequency [ count /s] & $5.13 \pm 0.25$ & $5.69 \pm 0.23$ & * \\
\hline 21 & Saccade Duration Total [ ms ] & $1705 \pm 134$ & $2290 \pm 226$ & * \\
\hline 22 & Saccade Duration Average [ms ] & $48.0 \pm 2.69$ & $46.4 \pm 3.17$ & \\
\hline 23 & Saccade Duration Maximum [ms ] & $111 \pm 7.52$ & $107 \pm 12.7$ & \\
\hline 24 & Saccade Duration Minimum [ms ] & $23.3 \pm 6.87$ & $22.9 \pm 4.35$ & \\
\hline 25 & Saccade Amplitude Total $\left[^{\circ}\right]$ & $203 \pm 7.05$ & $227 \pm 9.12$ & * \\
\hline 26 & Saccade Amplitude Average[ $\left.{ }^{\circ}\right]$ & $6.65 \pm 1.03$ & $5.19 \pm 2.04$ & \\
\hline 27 & Saccade Amplitude Maximum[ $\left[^{\circ}\right]$ & $31.5 \pm 3.87$ & $30.0 \pm 7.50$ & \\
\hline 28 & Saccade Amplitude Minimum $\left[{ }^{\circ}\right]$ & $1.36 \pm 0.89$ & $1.00 \pm 0.92$ & \\
\hline 29 & Saccade Velocity Total $\left[{ }^{\circ} / \mathrm{s}\right]$ & $3666 \pm 119$ & $4199 \pm 224$ & * \\
\hline 30 & Saccade Velocity Average $\left[{ }^{\circ} / \mathrm{s}\right]$ & $99.4 \pm 9.17$ & $87.7 \pm 11.25$ & \\
\hline 31 & Saccade Velocity Maximum $\left[{ }^{\circ} / \mathrm{s}\right]$ & $409 \pm 115$ & $349 \pm 57$ & \\
\hline 32 & Saccade Velocity Minimum $\left[{ }^{\circ} / \mathrm{s}\right]$ & $31.5 \pm 3.99$ & $28.0 \pm 2.75$ & \\
\hline 33 & Saccade Latency Average [ms ] & $159 \pm 31.6$ & $143 \pm 24.8$ & \\
\hline
\end{tabular}

Note: * - in comparison with field independent, $\mathrm{p} \leq 0.05$.

So, significantly more time is spent by field-dependent students to solve financial problems, this suggests that they take decisions longer. Regarding blinking, it should be noted that significant differences were found in the maximum duration of blinking only when solving winning problems with a probability of $99 \%$ and losing $-1 \%$. Thus, this factor is significantly higher for field-independent people, which indicates their greater emotionality in case of significant success and small losses. Significant differences in the parameters of fixations were also revealed. Thus, a greater number of fixations is typical for people with a field-dependent perceptual style. Field-independent individuals are characterized by low values of the total duration and maximum values of the average duration of fixations compared to individuals of group 2. The general and minimal dispersion of fixations is significantly higher among field-dependent students. Also, the maximum values of the length of the path travelled was identified, this confirms once again that 
they spend more time to solve this kind of problems.

The analysis of saccade parameters revealed that individuals with high articulated experience are characterized by lower values of the number, frequency and total duration of saccades in comparison with the representatives of the group. Field-dependent students showed the highest values of the total amplitude and total velocity of saccades compared to field-independent ones. It is interesting to note that the values of such saccade parameters as the minimum duration, amplitude and speed are significantly higher among people with a more independent perceptual style only when solving losing problems regardless of probability. When solving losing problems with a probability of $99 \%$, the latent period was longer for the field-independent students, that is, in such a situation, these people think longer. Consequently, the increase in the FD/FID index is associated with a decrease in the number of fixations, their duration and a decrease in the number and speed of saccades, which leads to a reduction in time, required for solving such tasks.

The obtained results indicate the presence of significant individual differences in OMA. A higher articulated perception among field independent students means both greater detailed elaboration and better organization of the perceptual field.

\section{Discussion}

According to the results of the study, it was established that the majority of students are on the border of rational and irrational financial behaviour, that is, in some cases, the risk is justified, and in some cases it is not. In winning situations, students take risk more often, regardless of cognitive style, but it is important to note that in situations with a high probability of losing more frequently the risk is taken by field independent persons. Various indicators of blinking, fixation and saccades allow us to conclude that students with a more independent perceptual style cope with such tasks faster. The increase in the FD / FID index is associated with a decrease in the number of fixations, their duration and a decrease in the number and speed of saccades, which leads to a reduction in the time required for solving financial problems. According to the number of blinking we can say that irrational students are more emotional. Financial decisions are made faster by rational individuals, based on the value of time spent and various indicators of fixations and saccades.

\section{Conclusion}

Cognitive style (field dependence / field independence) can be considered as a factor of financial decision-making. At the same time, cognitive style is interrelated with the degree of risk preference of the subject of financial decision-making, the type of decision-making strategy - rational, irrational or marginal, as well as the strategy of perceptual processing of information reflected in the features of oculomotor activity in the decision-making process, which determines its procedural features such as: the time spent on decision-making, the speed of decision-making, the emotional state of the individual during decisionmaking.

\section{Acknowledgments}

We thank students of Saratov National Research University named after N.G. Chernyshevsky for participation in our empirical experiments. We also would like to thank our colleagues from Economical Department for support and for comments that greatly improved the manuscript.

\section{Conflict of interests}

The authors declare no conflict of interest.

\section{References}

Akhtyamov, V. S. (2013). Psychological Conditions for Making Managerial Decisions by Managers in Stressful Situations. Dissertation abstract Candidate of Psychological Sciences, Moscow,24. Retrieved from http://nauka-pedagogika.com/ psihologiya-19-00-03/dissertaciya-psihologicheskie-usloviya-prinyatiya-upravlencheskih-resheniy-rukovoditelyami-vstressogennyh-situatsiyah

Ariely, D., Bracha, A., \& L'Huillier, J.-P. (2015). Public and Private Values. Journal of Behavioral Decision Making, 29(5), https:// 
Viktorovna T. B., \& Mikhailovna, Z. E. (2020). Field dependence / field independence as a factor of financial decision making with varying degrees of risk among students, International Journal of Cognitive Research in Science, Engineering and Education (IJCRSEE), (8), Special issue of Current Research and Trends in Cognitive Sciences 2020, 113-120.

doi.org/10.1002/bdm.1919

Ariely, D., Loewenstein, G., \& Prelec, D. (2003). "Coherent arbitrariness": Stable demand curves without stable preferences. The Quarterly journal of economics, 118(1), 73-106. https://doi.org/10.1162/00335530360535153

Ariely, D., \& Wertenbroch, K. (2002). Procrastination, deadlines, and performance: Self-control by precommitment. Psychological science, 13(3), 219-224. https://doi.org/10.1111/1467-9280.00441

Belykh, T. V. (2016). Making financial decisions with different degrees of risk: the neuro-and psychodynamic differences in the structure of individuality. Economic Psychology: Past, Present, Future, 3(2), 74-79. Retrieved from https://elibrary.ru/ item.asp?id=27213371

Belykh, T., Grishina, N., \& Zinchenko, E. (2018). Decision-making at different levels of rationality: subjects's cognitive, neural and psycho-dynamic characteristic. International journal of cognitive research in science, engineering and education, 6(1), 39-44. https://doi.org/10.5937/ijcrsee1801039B

Bryukhova, N. G. (2007). Influence of self-understanding on decision-making by young men and girls. Dissertation abstract Candidate of Psychological Sciences, Astrakhan, 22. Retrieved from http://www.dissercat.com/content/vliyaniesamoponimaniya-na-prinyatie-reshenii-yunoshami-i-devushkami

Carmon, Z., \& Ariely, D. (2000). Focusing on the forgone: How value can appear so different to buyers and sellers. Journal of consumer research, 27(3), 360-370. https://doi.org/10.1086/317590

Chechin, V. V. (2017). Objective conditions for the creation of a modern methodical approach to decision making on the securities market. PUF, 25. 28-33. Retrieved from https://cyberleninka.ru/article/v/obektivnye-usloviya-sozdaniyasovremennogo-metodicheskogo-podhoda-prinyatiya-resheniya-na-rynke-tsennyh-bumag

Gladkikh, N. Yu. (2011). Specificity of decision-making processes in a situation of advertising influence. Dissertation abstract Candidate of Psychological Sciences,Yaroslavl, 24. Retrieved from http://www.dissercat.com/content/spetsifikaprotsessov-prinyatiya-reshenii-v-situatsii-reklamnogo-vozdeistviya

Goretskaya, V. A. (2014). Behavioral finance: the application of the theory of prospects in financial management. Finance and credit, 4(580). Retrieved from https://www.fin-izdat.com/journal/fc/detail.php?ID=60427

Gottschaldt, K. (1926) Uber den Einfluss der Erfahrung auf die Wahrnehmung von Figuren. Psychol. Forsch, 8, $261-317$. https://doi.org/10.1007/BF02411523

Grishina, N. P. (2012). The problem of making investment decisions from the point of view of the practice of behavioral finance. Bulletin of the Saratov State Socio-Economic University, 1(40). Retrieved from https://cyberleninka.ru/article/n/ problema-prinyatiya-investitsionnyh-resheniy-s-tochki-zreniya-praktiki-povedencheskih-finansov

Kahneman, D., \& Tversky, A. (1979). Prospect theory: an analysis of decision under risk. Econometrica, 47, 263-291. Retrieved from https://www.uzh.ch/cmsssl/suz/dam/jcr:00000000-64a0-5b1c-0000-00003b7ec704/10.05-kahneman-tversky-79. pdf

Kholodnaya, M. A. (1997). Psychology of intelligence: research paradoxes, Tomsk, 392. Retrieved from https://gigabaza.ru/ doc/14089-pall.html

Kholodnaya, M. A. (2002). Cognitive styles: the nature of the individual mind / MA Cold M.: PER SE, 304 pp.

Kholodnaya, M. A. (1990). Cognitive styles as a manifestation of the uniqueness of individual intelligence. UMK VO Kiev, 73.

Kholodnaya, MA (1992). Cognitive styles and intellectual abilities. Psychol. Journal, 13(3), 84-93. Retrieved from https:/l elibrary.ru/item. asp?id=20193930

Kornilova, T. V. (2010). Intellectual and personal potential of a person in coping strategies. Moscow University Bulletin. Psychology, 14(1), 46-57. Retrieved from https://cyberleninka.ru/article/v/intellektualno-lichnostnyy-potentsialcheloveka-v-strategiyah-sovladaniya

Kornilova, T. V. (2002). Motivational regulation of decision-making: modern views. Modern psychology of motivation / Edited by DA. Leontiev, Moscow, Meaning, 172-213. Retrieved from http://world-psychology.ru/wp-content/ uploads/2014/06/0100574_B1910_leontev_d_a_sovremennaya_psihologiya_motivacii.pdf\#page=173

Korshunova, G. S., Nemtsev, A. D., \& Romanova, L. $\bar{E}$. (2017). Behavioral finance: the laws of financial decision-making. Vestnik of the Volga University named after Tatishcheva, 2(2), 1-10. Retrieved from https://cyberleninka.ru/article/v/ povedencheskie-finansy-zakonomernosti-prinyatiya-resheniy-finansovogo-haraktera

Krivosheeva, N. W. (2008). The study of the socio-psychological readiness of students and future managers to make management decisions. Dissertation abstract Candidate of Psychological Sciences, Moscow, 22. Retrieved from http://www.dissercat.com/content/issledovanie-sotsialno-psikhologicheskoi-gotovnosti-studentov-budushchikhrukovoditelei-k-p-0

Loewenstein, G. (1996). Out of control: Visceral influences on behavior. Organizational behavior and human decision processes, 65(3), 272-292. https://doi.org/10.1006/obhd.1996.0028

Markowitz, H. (1952). Portfolio selection. The Journal of Finance, 7(1), 77-91. https://doi.org/10.2307/2975974

Mordashkina, Yu. (2013). Psychological Aspects of Forming an Investment Decision Making Mechanism. Russian Journal of Entrepreneurship, 9(231). Retrieved from https://cyberleninka.ru/article/v/psihologicheskie-aspekty-formirovaniyamehanizma-prinyatiya-investitsionnyh-resheniy

Nenasheva, E. V. (2009). Forecasting the profitability of financial assets in the capital markets, taking into account the behavioral characteristics of investors. Dissertation abstract Candidate of Economic Sciences, Moscow, 33. Retrieved from https://www.econ.msu.ru/cmt2/lib/a/1571/file/Nenasheva.pdf

Neumann, J., \& Morgenstein, O. (1970). Game theory and economic behavior. Moscow, Progress, 103. Retrieved from http:// bourabai.kz/dm/gamestheory1.htm

Osokina, K. A. (2016). Interrelation of cognitive style (field-dependence-field independence) and some personality traits. Vestnik KSPU after V. P. Astafieva, 4(38), 255-257. Retrieved from https://cyberleninka.ru/article/v/vzaimosvyaz-kognitivnogostilya-polezavisimost-polenezavisimost-i-nekotoryh-svoystv-lichnosti

Petty, R. E., \& Cacioppo, J. T. (1986). The elaboration likelihood model of persuasion. In L. Berkowitz (Ed.), Advances in experimental social psychology (Vol. 19, pp. 123-205). New York: Academic Press. https://doi.org/10.1016/S00652601(08)60214-2

Ponomarev, V. P. (2011). The adoption of innovative solutions as managerial competence on the example: of a high school leader. Dissertation abstract Candidate of Psychological Sciences, Moscow, 21. Retrieved from http://www.dissercat. 
Viktorovna T. B., \& Mikhailovna, Z. E. (2020). Field dependence / field independence as a factor of financial decision making with varying degrees of risk among students, International Journal of Cognitive Research in Science, Engineering and Education (IJCRSEE), (8), Special issue of Current Research and Trends in Cognitive Sciences 2020, 113-120.

com/content/prinyatie-innovatsionnykh-reshenii-kak-upravlencheskaya-kompetentnost

Predein, E. V. (2012). Cognitive style "field dependence - field independence"/ E. V. Predein. Published at the site: January 13, Retrieved from http://www.b17.ru/article/4203/ [electronic resource].

Rumyantseva, A. V. (2008). Features of decision-making by high school students in risk situations. Dissertation abstract Candidate of Psychological Sciences, St. Petersburg, 24. Retrieved from http://www.dslib.net/psixologia-razvitja/ osobennosti-prinjatija-reshenij-starsheklassnikami-v-situacijah-riska.html

Samson, A. (2015). The Behavioral Economics Guide 2015 (with an introduction by Dan Ariely introduction). Retrieved from http://eprints.Ise.ac.uk/64439/1/BEGuide2015.pdf

Semicheva, N. V. (2010). Cognitive-stylistic decision-making determination. Dissertation abstract Candidate of Psychological Sciences, Moscow, 24. Retrieved from http://www.dissercat.com/content/kognitivno-stilevaya-determinatsiyaprinyatiya-reshenii

Semyashkin, A. A. (2010). Gender differences in the relationship of cognitive styles and temperament. Vestnik TSPU, 2(92), 130-134. Retrieved from https://cyberleninka.ru/article/v/gendernye-razlichiya-vo-vzaimosvyazyah-kognitivnyh-stiley-itemperamenta

Shiv B., Carmon Z., \& Ariely D. Placebo (2005). Effects of Marketing Actions: Consumers May Get What They Pay For. Journal of Marketing Research., XLII, 383-393 Retrieved from http://people.duke.edu/ dandan/webfiles/PapersPI/ Placebo\%20Marketing\%20Actions.pdf

Shkuratova, I. P. (1994). Cognitive style and communication, Rostov-on-Don, RSPU, 156.

Shkuratova, I. P. (1999). Cognitive styles and their impact on the success of communication and learning. Methodical manual for the course "Psychology of cognitive processes", Rostov-on-Don. 95. Retrieved from https://irshkuratova.ru/kog_ stili_uspeshnost_obshenija-obuchenija.html

The style of man. Psychological analysis (1998). (Ed. A.V. Libin). M.: Meaning, 310.

Tikhomirova, I. V. (1988). Style and productive characteristics of abilities: a typological approach. Questions of psychology, 3, 106-115.

Vavilov, S. V. (2006). Psychological management space. Sociological research, 5, 93-102. Retrieved from http://ecsocman. hse.ru/data/770/662/1216/Sotsis_5_06_p93-102.pdf

Witkin, H., Goodenough, D. (1981). Cognitive styles, essence and origins: field dependence and field independence, N.Y., 135. Retrieved from https://catalogue.nla.gov.au/Record/1474010

Witkin, H. \& Others (1977). A Longitudinal Study of the Role of Cognitive Styles in Academic Evolution During the College Years (microform] [Washington, D.C.)): Distributed by ERIC Clearinghouse, 131. Retrieved from https://eric. ed.gov/?id=ED165613

Zaguzova, T. A. (2009). Gender, age and individual-personality differences in decision-making processes. Dissertation abstract Candidate of Psychological Sciences, Moscow, 21. Retrieved from http://www.dissercat.com/content/gendernyevozrastnye-i-individualno-lichnostnye-razlichiya-v-protsessakh-prinyatiya-reshenii 